\title{
NOTES ON NEW ENGLAND BOMBYLIIDAE, WITH A DESCRIPTION
} OF A NEW SPECIES OF ANTHRAX.

BY CHARLES W. JOHNSON, BOSTON, MASS.

\section{Anthrax shawiI n. sp.}

$\sigma^{\top}$ 우. Face and front black, with blackish pile and tomentum, that on the face showing in certain lights a whitish reflection, occiput black, with a silvery white tomentum; antennae black. Thorax and abdomen black, front and sides of the thorax, margins of the scutellum, and sides of the abdomen to the base of the third segment, bordered with dark orange red pile; dorsum of the thorax and disc of the scutellum with black tomentum showing a whitish reflection. Abdomen with two broad bands of yellowish white tomentum, the one on the second segment occupying the basal half, while that on the fourth covers the entire segment the last segment is also covered with yellowish tomentum margined with black, a few scattered yellowish scales sometimes present on sixth segment. Legs black, wings hyaline, the costal cells and base, including the alulet dark brown. Length $6 \mathrm{~mm}$.

Five specimens of this interesting little species were collected by Mr. S. Albert Shaw, among the sandhills at Hampton Beach, N. H., August 27, 1906. Types in the New England collection of the Boston Society of Natural History. Paratypes in Mr. Shaw's and the author's collection. Through the kindness of Mr. A. H. Kirkland, I have also seen a specimen from Westport, Mass., Sept., 1907.

The species resembles some of the smaller examples of $A$. lateralis Say, but can be readily separated, by the dark tomentum of the face, the dark orange-red (not yellow) pile and dark costal cells.

Anthrax lateralis Say.

This variable and widely distributed species has in the Eastern United States two well marked variations which cause considerable confusion when lumped with the typical form. In order to eliminate this confusion provisionally I will briefly define the two forms. The one more commonly observed has the tomentum on the front black, on the face it is grayish, but in certain lights blackish; anterior margin of the thorax, pleurae and sides of the first two segments of the abdomen, with yellow pile; entire dorsum of the thorax, the middle of the first and second segments and all the other segments of the abdomen with black tomentum and pile. In some specimens there is a faint band of yellow tomentum at the base of the fourth segment and more or less prominent tufts of silvery tomentum on the terminal segment. 
They vary in length from 7 to $11 \mathrm{~mm}$. This seems to be the only form that can, with any certainty be referred to Macquart's gracilis "Face et front à poils noirs. Un peu de fond testacé sur les côtés des deux premiers segments de l'abdomen. Long. $4 \frac{1}{4} \mathrm{l}$. ㅇ”. The varietal name of gracilis might therefore be used. Specimens are before me from Cranberry, N. C., June 10, '96 (H.W.Wenzel); Westville, N. J., June 15, '94 (C.W. Johnson); Lehigh Gap, Pa., July 2, '01 (H. L. Viereck) Lake Pleasant, N. Y. (Dr. E. G. Love). Woods Hole, Mass., July 24, '03 (Johnson) Jaffrey, N. H.; Waterville, Me., July 19, '07 and Hampden, Me., Aug. 16, ’07 (E. F. Hitchings).

In appearance it seems to hold the same relation to the typical lateralis that hypomelas holds to alternata, although in the latter case hypomelas is considered a good species. The group should be carefully studied in connection with some of the western species.

The other is a small form 6 to $7 \mathrm{~mm}$. in length, with white tomentum and pile. The only yellow tomentum is a small triangular patch in front of the scutellum and sometimes scattered scales on the terminal segment of the abdomen. The second, third and fourth segments have prominent basal bands of white tomentum. This form seems to be more numerous in the spring. It was collected at Riverton, N. J., April 30; at Clementon, N. J., numerous specimens were taken from May 16 to 30, flying over the white sand; it was also collected among the sand dunes back of Provincetown, Mass., June 25, 1904. The varietal name of arenicola might be applied to this form.

A number of other interesting species of Bombylidae have been added to the New England fauna, including:-- Spogostylum albofasciatum Macq., Provincetown, Mass., June 25-27, 1904. Spogostylum pauper Loew, Provincetown, Mass., June 25; Manomet, Mass., July 17, (J.A.Cushman). Oncodocera leucoprocta Wied., West Bedford, Mass., June 8, 1906 (L. W. Swett). Phthiria coquilleti Johnson, Nantucket, Mass., July 4, '06 (J.A.Cushman). The latter were slightly smaller than the types collected at Riverton, N. J. 

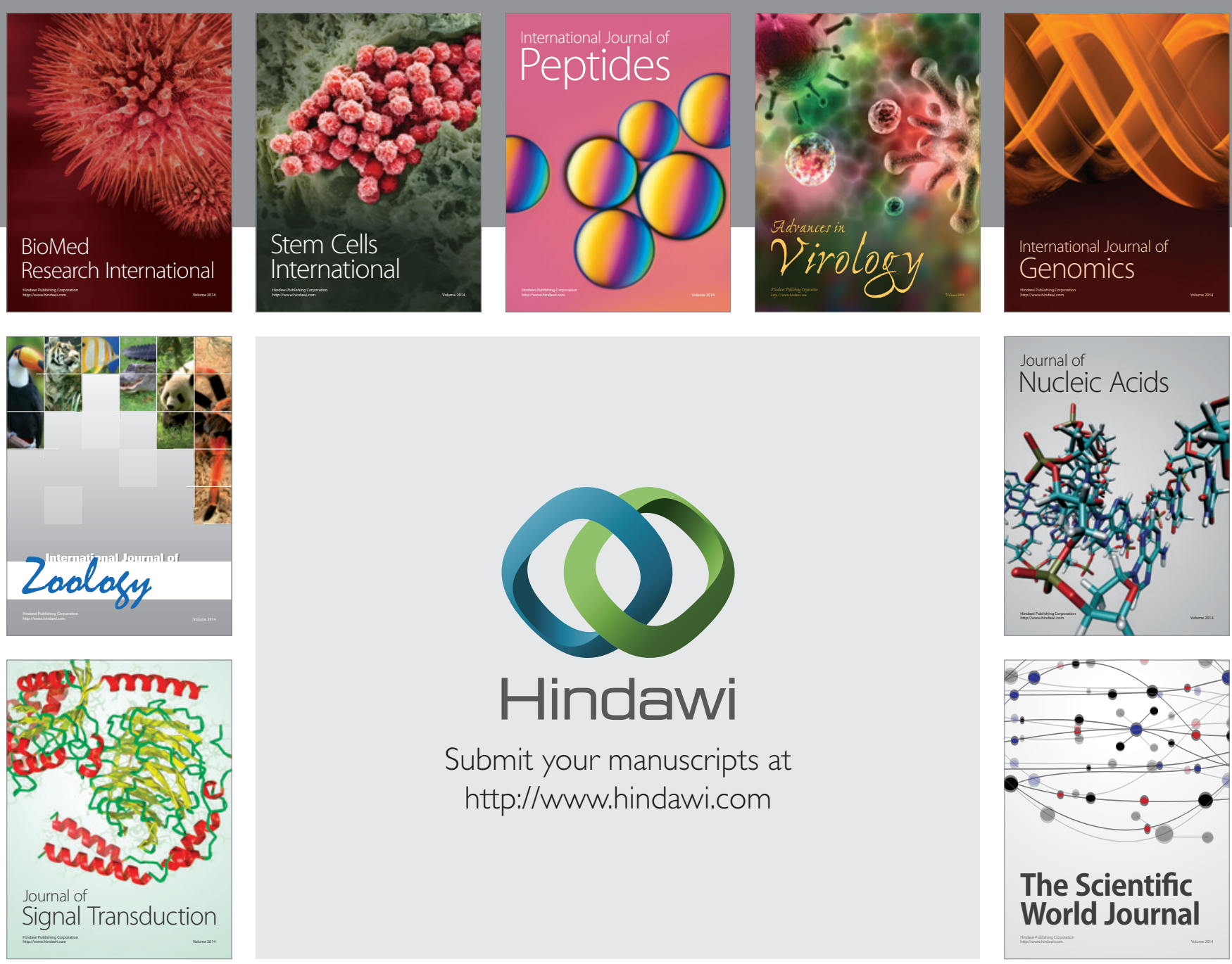

Submit your manuscripts at

http://www.hindawi.com
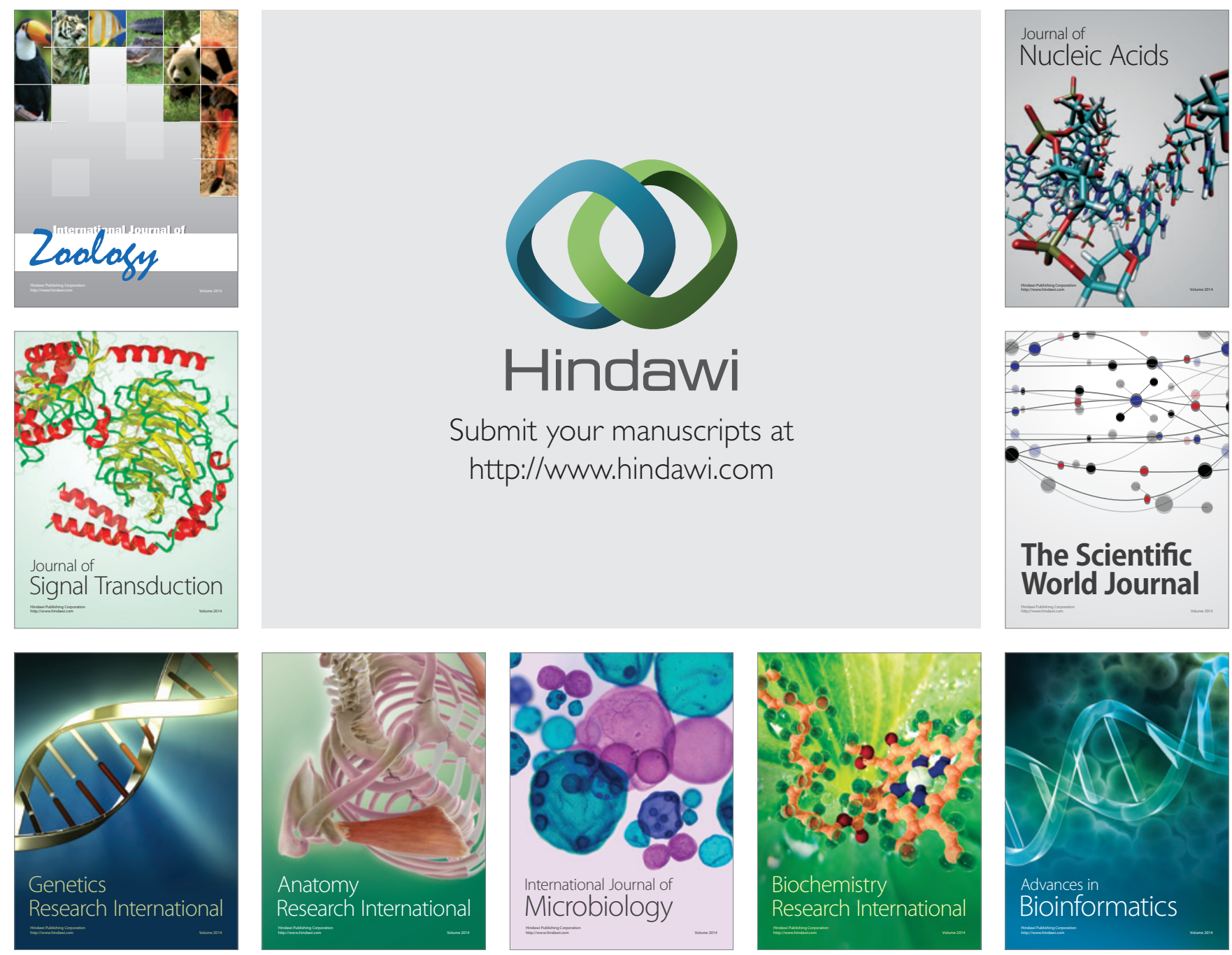

The Scientific World Journal
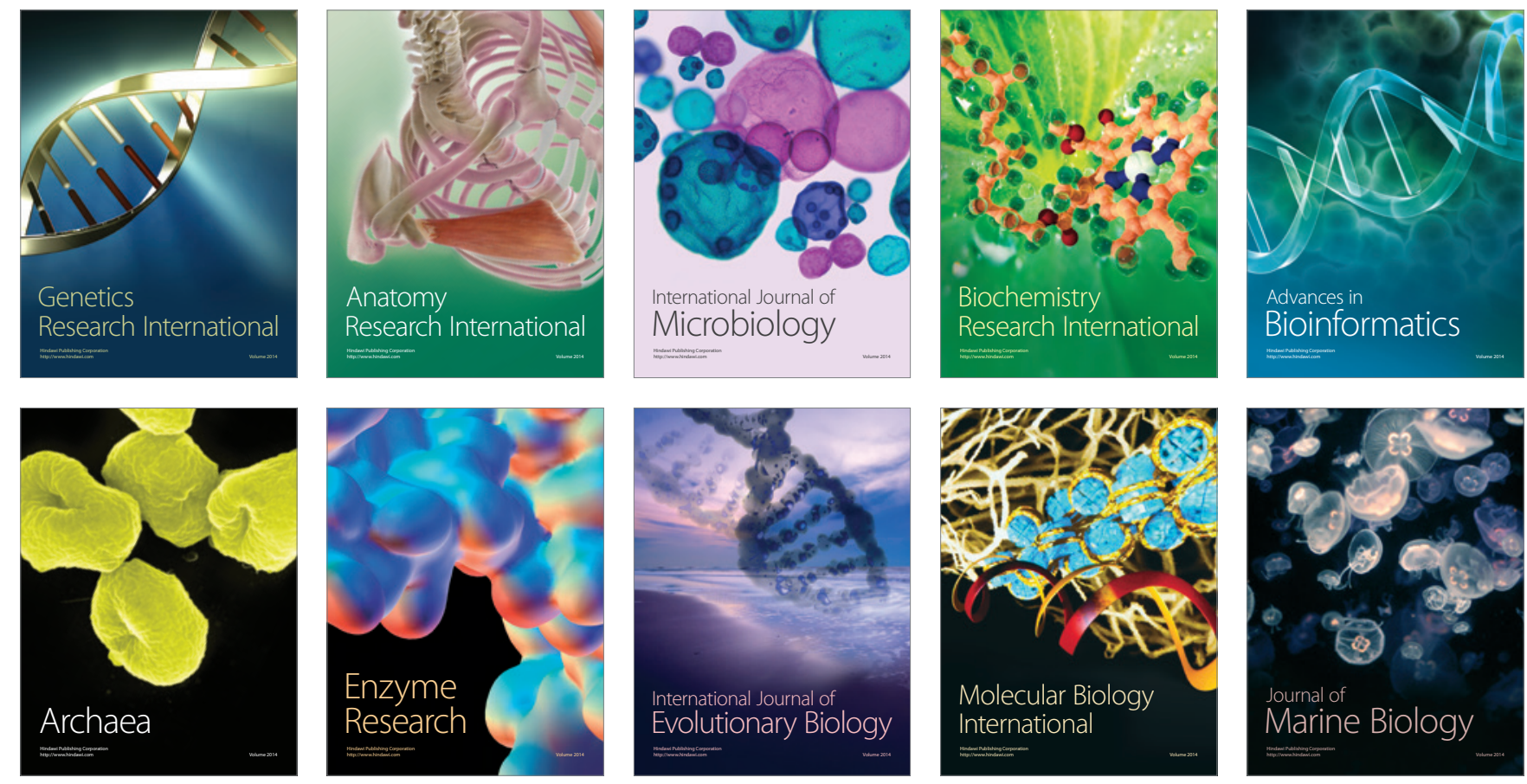